\title{
PENGARUH PENGGUNAAN MODEL KOOPERATIF TIPE NUMBERED HEAD TOGETHER TERHADAP HASIL BELAJAR PKN DISEKOLAH DASAR Oleh:
}

\author{
Syafrina ${ }^{1)}$ Reinita ${ }^{2)}$ Mansur $^{3)}$ \\ ${ }^{1)}$ Mahasiswa, Universitas Negeri Padang, Indonesia \\ ${ }^{2)}$ Pembimbing 1, Universitas Negeri Padang, Indonesia \\ ${ }^{3)}$ Pembimbing 2, Universitas Negeri Padang, Indonesia \\ ${ }^{1}$ syafrinaarsyila25@gmail.com , ${ }^{2}$ reinita_reinita@yahoo.com, \\ 3)mansurlubis1954@yahoo.com
}

\begin{abstract}
Abstrak
Penelitian ini bertujuan untuk mengetahui pengaruh penggunaan model kooperatif tipe Numbered Head Together terhadap hasil belajar PKn. Jenis penelitian ini adalah penelitian eksperimen dengan desain Quasi Exsperimen desaign dengan bentuk nonequivalent control group design. Sampel dalam penelitian ini adalah kelas VA dan kelas VB. Hasil perhitungan data penelitian yang digunakan adalah uji-t diperoleh $\mathrm{t}_{\text {hitung }} 2,26>\mathrm{t}_{\text {tabel }} 1,67722$ pada taraf $\alpha 0,05$. Dengan demikian dapat disimpulkan bahwa terdapat pengaruh yang signifikan antara penggunaan model kooperatif tipe Numbered Head Together terhadap hasil belajar PKn kelas V SDN 13 Cingkariang Kecamatan Banuhampu Kabupaten Agam
\end{abstract}

Kata Kunci: Model NHT, Hasil Belajar PKn.

\section{Abstrack}

This study purpose to determine the effect influence of the use cooperative type Numbered Head Together to the civic education learning outcomes. This research is an experimental research design with Quasi Exsperimental. The sample in this research is class VA and class VB. The calculation result of research data used was obtained t $t$-test 2,26 $>1.67722 t_{\text {able }}$ at a level of 0.05. With it can be concluded that there is significant influence of the use cooperative tipe Numbered Head Together to the civic education learning outcomes of class V SDN 13 Cingkariang Kecamatan Banuhampu Kabupaten Agam.

Key Word : Model NHT, Learning Outcomes of the civic education 


\section{PENDAHULUAN}

Model pembelajaran kooperatif merupakan salah satu model pembelajaran yang inovatif yang dapat membantu siswa memahami materi pembelajaran melalui belajar kelompok, sehingga dapat mencapai hasil belajar yang optimal. Model pembelajaran kooperatif dikembangkan untuk mencapai hasil belajar berupa prestasi akademik, toleransi, menerima keragaman, dan mengembangkan keterampilan sosial. Dengan model kooperatif ini, siswa dapat berkesempatan untuk berkomunikasi dan menjalin interaksi sosial dengan sesama siswa karena guru dalam pembelajaran bertindak sebagai motivator dan fasilitator untuk siswa.

Model kooperatif ini sangat beragam, salah satunya adalah model pembelajaran kooperatif tipe Numbered Head Together. Numbered Head Together (NHT) pertama kali dikembangkan oleh Spenser Kagen (1993) Menurut Hamdayana (2014:175) pembelajaran kooperatif tipe Numbered Head Together merupakan jenis pembelajaran kooperatif yang dirancang memengaruhi pola interaksi siswa dan sebagai alternative terhadap sumber struktur kelas tradisional untuk melibatkan siswa dalam menelaah materi yang tercakup dalam suatu pelajaran dan mengecek pemahaman mereka terhadap isi pembelajaran. Sejalan dengan hal tersebut menurut Trianto (2011:82) bahwa "Numbered Head Together merupakan jenis pembelajaran kooperatif yang dirancang untuk mempengaruhi pola interaksi siswa dalam suatu pembelajaran dimana setiap peserta didik diberi nomor kemudian suatu kelompok kemudian secara acak guru memanggil nomor dari peserta didik."

Model Numbered Head Together (NHT) ini memiliki banyak kelebihan yang dapat menunjang pembelajaran. Menurut Kurniasih (2015:30-31) bahwa model pembelajaran kooperatif tipe Numbered Head Together mempunyai keunggulan yaitu 1) Dapat meningkatkan prestasi belajar siswa, 2) Mampu memperdalam pemahaman siswa, 3) Melatih tanggung jawab siswa, 4) Menyenangkan siswa dalam belajar, 5)Mengembangkan rasa ingin tau siswa, 6) Meningkatkan rasa percaya diri siswa, 7) Mengembangkan rasa saling memiliki dan kerja sama, 8) Setiap siswa termotivasi untuk menguasai materi, 9) Menghilangkan kesenjangan antara yang pintar dengan tidak pintar.

Model pembelajaran kooperatif tipe NHT cocok digunakan dalam pembelajaran sosial salah satunya pembelajaran Pendidikan 
Kewarganegaraan (PKn). Karena penggunaan model pembelajaran yang tepat dalam pembelajaran akan membuat siswa lebih menguasai materi dan diharapkan siswa mampu meningkatkan hasil belajar. Pendidikan kewarganegaraan merupakan salah satu mata pelajaran yang wajib dipelajarioleh setiap siswa pada setiap tingkat maupun jenjang pendidikannya begitu juga disekolah dasar (SD).

Mata pelajaran PKn tidak hanya menanamkan konsep pengetahuan semata,tetapi di dalam PKn harus memuat semua aspek pendidian kewarganegaraan,seperti penanaman sikap dan keterampilan sebagai bekal dalam membentuk warga negara yang demokratis. Mata pelajaran PKn bertujuan agar siswa memiliki kemampuan berpikir secara kritis, rasional, dan kreatif dalam menanggapi isu kewarganegaraan, berpartisipasi secara aktif dan kreatif dalam bertangggung jawab, bertindak secara cerdas, berbangsa dan bernegara serta anti korupsi,berkembang secara positif dan demokratis untuk membentuk diri berdasarkan karakter-karakter masyarakat Indonesia agar dapat hidup bersama dengan bangsa lainnya, berinteraksi dengan bangsa-bangsa lain dalam pencaturan dunia secara langsung atau tidak langsung dengan

memanfaatkan teknologi dan komunikasi.

Berdasarkan dari data yang peneliti peroleh dilapangan di SDN 13 Cingkariang Kecamatan Banuhampu Kabupaten Agam pada tanggal 26 Juli 2017 khususnya kelas V terdapat beberapa masalah yang mendukung penelitian ini. Pada saat proses pembelajaran berlangsung, kurangnya penggunaan model pembelajaran oleh guru. Guru dalam pembelajaran belum menggunakan model yang bervariasi termasuk model NHT. Selain itu guru kurang melibatkan siswa secara aktif sehingga interaksi guru dengan siswa kurang optimal. Hal inilah yang menyebabkan mayoritas siswa masih pasif, kurang berinteraksi sehingga rendahnya hasil belajar siswa khususnya pada mata pelajaran PKn.

Jika kondisi pembelajaran yang digambarkan di atas dibiarkan terus berlanjut, maka akan berdampak negatif pada hasil belajar siswa di kelas V SDN 13 Cingkariang. Untuk mengatasi kondisi di atas, perlu diadakan penggunaan model pembelajaran, salah satunya yaitu dengan menggunakan model pembelajaran kooperatif tipe NHT.

Penelitian ini bertujuan untuk mengetahui pengaruh penggunaan model kooperatif tipe Numbered Heads 
Together (NHT) terhadap hasil belajar Pendidikan kewarganegaraan siswa kelas V di SDN 13 Cingkariang Kecamatan Banuhampu Kabupaten Agam.

\section{METODE PENELITIAN}

Penelitian ini merupakan penelitian eksperimen dengan jenis quasi eksperimental design dengan bentuk nonequivalent control group design yang menggunakan metode penelitian kuantitatif. Penelitian kuantitatif adalah penelitian yang dilakukan dengan mengumpulkan data berupa angka, yang akan diolah dan kemudian dianalisis untuk mendapatkan informasi ilmiah dibalik angka tersebut. Menurut Arikunto (2010:9) bahwa "eksperimen adalah suatu cara untuk mencari hubungan sebab-akibat antara dua faktor yang sengaja ditimbulkan oleh peneliti dengan mengurangi atau menyisihkan faktor-faktor lain yang menganggu." Eksperimen biasa dilakukan dengan maksud untuk melihat akibat suatu perlakuan.

Desain atau rancangan ini digunakan untuk mengetahui pengaruh model Numbered Head Together terhadap hasil belajar Pendidikan kewarganegaraan kelas V SDN 13 Cingkariang Kecamatan Banuhampu Kabupaten Agam. Alasan lain peneliti menggunakan desain ini karena dalam menentukan kelas eksperimen dan kelas kontrol tidak dilakukan secara acak. Hal ini dapat memudahkan peneliti dalam melaksanakan penelitian di SDN 13 Cingkariang Kecamatan Banuhampu

$$
\text { Menurut Sugiyono (2012:116) }
$$
rancangan (desain) penelitian Nonequivalent Control Group Design dapat digambarkan sebagai berikut:

Tabel 1 Analisis Kelompok dengan Desain Penelitian Nonequivalen

\begin{tabular}{|l|l|l|l|}
\hline Kelas & $\begin{array}{l}\text { Pre } \\
\text { test }\end{array}$ & $\begin{array}{l}\text { Treat } \\
\text { ment }\end{array}$ & $\begin{array}{l}\text { Post } \\
\text { test }\end{array}$ \\
\hline Eksperimen & $\mathrm{O} 1$ & $\mathrm{X}$ & $\mathrm{O} 2$ \\
\hline Kontrol & $\mathrm{O} 3$ & - & $\mathrm{O} 4$ \\
\hline
\end{tabular}

Sumber : Sugiyono (2012:116)

$\mathrm{O} 1$ :hasil pre-test kemandirian belajar kelas eksperimen

$\mathrm{O} 2$ :hasil post-test kemandirian belajar kelas eksperimen

O3 :hasil pre-test hasil belajar kelas kontrol

$\mathrm{O} 4$ :hasil post test hasil belajar kelas kontrol

$\mathrm{X}$ :Perlakuan. Kelas eksperimen diberi perlakuan berupa pembelajaran dengan model pembelajaran kooperatif tipe Numbered Head Together

__ :Tanpa perlakuan (Konvensional). Kelas kontrol diberi perlakuan dengan kondisi belajar yang wajar atau pembelajaran yang 
biasanya dilakukan oleh guru yaituceramah dan tanya jawab atau penugasan.

Populasi penelitian adalah seluruh subjek atau objek penelitian yang memenuhi syarat-syarat tertentu berkaitan dengan masalah penelitian. Maka pada penelitian ini yang dijadikan populasi adalah seluruh siswa kelas $\mathrm{V}$ SDN 13 Cingkariang yang berjumlah 50 orang.Teknik sampling yang digunakan dalam penelitian ini adalah total sampling yang mewakili jumlah populasi. Biasanya dilakukan jika populasi dianggap kecil atau kurang dari 100. Sedangkan sampel dalam penelitian ini adalah siswa kelas V SDN 13 Cingkariang yang terdiri dari dua kelas yang masing-masing berjumlah 25 orang. Dimana kelas eksperimen (VA) jumlah siswa laki-laki 13 orang, julah siswa perempuan 12 orang. Sedangkan kelas control (VB) jumlah siswa laki-lki 14 orang, jumlah siswa perempuan 11 orang.

Instrument penelitian dalam penelitian ini adalah tes. Peneliti hanya menggunakan instrument tes ini karena peneliti ingin mengukur variabel terikat yaitu hasil belajar pendidikan kewarganegaraan terutama pada materi mengenal bentuk-bentuk keputusan bersama.Instrumen tes yang dugunakan dalam penelitian ini berupa tes tertulis dalam bentuk tes objektif dengan jenis tes pilihan ganda dengan empat alternatif pilihan jawaban dimana soalsoal dibuat berdasarkan kisi-kisi sesuai dengan indikator yang hendak dicapai.Tes dilakukan sesudah perlakuan (post-test) yang diberikan pada kedua kelas baik kelas eksperimen maupun kelas kontrol.

Setelah soal tes dibuat berdasarkan kisi-kisi yang telah ditentukan maka soal tes tersebut harus diujicobakan untuk melihat seberapa besar kualitas instrument penelitian yang dapat digunakan pada penelitian ini nantinya. Pada penelitian ini uji coba instrument dilakukan pada kelas VI di SDN 01 Cimpago Ipuh.Soal tes yang telah di uji cobakan akan diperiksa terlebih dahulu, dimana setiap jawaban benar diberi bobot nilai 1 dan jawaban salah diberi bobot nilai 0 . Kemudian hasil uji coba instrument tersebut perlu dianalisis untuk melihat validitas, reabilitas, tingkat kesukaran, dan daya beda soal. Sehingga dari 30 soal yang diujicobakan dan dianalisis terlihatlah soal mana saja yang baik digunakan sebagai instrument penelitian.

Berdasarkan hasil validitas soal yang diujicobakan di kelas VI SD Negeri 01 Campago Ipuh dan berdasarkan hasil perhitungan 
menggunakan bantuan Microsoft Excel, diperoleh data bahwa dari 30 soal bentuk pilihan ganda yang diujicobakan terdapat 25 soal yang dinyatakan valid. Instrument yang dinyatakan valid yaitu soal nomor $1,2,3,4,5,6,7,8,9,11$, $12,13,14,15,16,17,19,21,22,23,26$, 27, 28, 29, 30. Sedangkan instrument yang dinyatakan tidak valid yaitu nomor 10, 18, 20, 24 dan 25. Untuk perhitungan uji coba reliabilitas instrument tes yang dihitung menggunakan perhitungan manual diperoleh hasil reliabilitas tes sebesar 0,74 dengan kategori tinggi. Hasil uji coba yang telah dilakukan diperoleh hasil indeks tingkat kesukaran melalui perhitungan manual terdapat soal dengan krteria sukar sebanyak 4 soal, kriteria sedang sebanyak 13 soal, dan kriteria mudah sebanyak 13 soal. Sebelum dilakukan uji hipotesis terlebih dahulu dilakukan uji prasyarat analisis yaitu menganalisis uji normalitas dan menganalisis uji homogenitas data sebagai persyaratan penggunaan statistik parametrik.Hipotesis penelitian diuji dengan menggunakan rumus uji-t.

$\begin{array}{rccc}\text { Data } & \text { yang } & \text { diperoleh dalam } \\ \text { penelitian } & \text { akan dianalisis dengan }\end{array}$
parametrik. Sebelum dilakukan uji hipotesis terlebih dahulu dilakukan uji prasyarat analisis yaitu menganalisis uji normalitas dan menganalisis uji homogenitas data sebagai persyaratan penggunaan statistik parametrik.Hipotesis penelitian diuji dengan menggunakan rumus ujit.Kriteria pengujian $\mathrm{H}_{0}$ ditolak jika $\mathrm{t}_{\text {hitung }}$ $\mathrm{tt}_{\text {abel}}$, dengan taraf signifikansi 5\%.Uji hipotesis yang dilakukan dalam penelitian ini menggunakan Uji-t .

\section{HASIL DAN PEMBAHASAN}

Hasil penelitian disajikan dalam bentuk tabel dan deskriptif. dimana nilai tes akhir antara siswa yang mengikuti tes akhir kelompok eksperimen dan kontrol dapat dilihat pada tabel di bawah ini.

Tabel 2 Deskripsi Data Tes akhir Kelompok Eksperimen dan Kontrol

\begin{tabular}{|c|c|c|}
\hline \multirow{2}{*}{ Deskripsi } & \multicolumn{2}{|c|}{ Tes Akhir } \\
\cline { 2 - 3 } & $\begin{array}{c}\text { Kelas } \\
\text { Eksprimen }\end{array}$ & $\begin{array}{c}\text { Kelas } \\
\text { Kontrol }\end{array}$ \\
\hline $\mathrm{N}$ & 25 & 25 \\
\hline $\begin{array}{c}\text { Nilai } \\
\text { tertinggi }\end{array}$ & 84 & 80 \\
\hline $\begin{array}{c}\text { Nilai } \\
\text { terendah }\end{array}$ & 48 & 48 \\
\hline Mean & 68,16 & 62,72 \\
\hline Varians & 76,64 & 70,50667 \\
\hline $\begin{array}{c}\text { Standar } \\
\text { deviasi }\end{array}$ & 8,39 & 8,3968 \\
\hline
\end{tabular}

Dari tabel diatas diketahui bahwa perolehan nilai tes akhir siswa pada kelas eksperimen nilai tertinggi adalah 84 dan nilai terendah 48 , nilai rata-rata 
68,16 , varians 76,64 dan standar deviasi 8,39. Adapun perolehan nilai tes akhir kelas kontrol nilai tertinggi 80 dan nilai terendah yaitu 48 , nilai rata-rata 62,72 , varians 70,50667 dan standar deviasi 8,3968. Dari penjelasan diatas dapat disimpulkan bahwa perolehan nilai posttest kelas eksperimen lebih tinggi daripada kelas kontrol. Sehingga dapat dikatakan bahwa pembelajaran pendidikan kewarganegaraan dengan menggunakan model kooperatif tipe NHT berpengaruh dibandingkan dengan menggunakan metode ceramah bervariasi.

Setelah data hasil penelitian di dapat, maka data akan diolah melalui uji hipotesis. Sebelum melakukan uji hipotesis, terlebih dahulu dilakukan pengujian prasyarat analisis data, yaitu uji normalitas dan homogenitas guna mengetahui apakah data yang diperoleh terdistribusi normal atau tidak. Adapun hasil Hasil uji normalitas tes akhir pada kelas eksprimen dan kelas kontrol adalah sebagai berikut.

Tabel 3. Hasil Uji Normalitas Postest

kelas Eksprimen dan Kontrol

\begin{tabular}{|l|c|c|c|c|c|}
\hline \multicolumn{1}{|c|}{ Kelas } & $\mathbf{N}$ & $\mathbf{A}$ & $\begin{array}{c}\text { Lo } \\
\text { (hitung) }\end{array}$ & $\begin{array}{c}\mathbf{L} \\
\text { tabel }\end{array}$ & $\begin{array}{c}\text { Kesimpul } \\
\text { an }\end{array}$ \\
\hline $\begin{array}{l}\text { Eksperim } \\
\text { en }\end{array}$ & $\begin{array}{c}2 \\
5\end{array}$ & $\begin{array}{c}0.0 \\
5\end{array}$ & $\begin{array}{c}0,0356 \\
27\end{array}$ & $\begin{array}{c}0,17 \\
3\end{array}$ & $\begin{array}{c}\text { DistribusI } \\
\text { Normal }\end{array}$ \\
\hline Kontrol & $\begin{array}{c}2 \\
5\end{array}$ & $\begin{array}{c}0.0 \\
5\end{array}$ & $\begin{array}{c}0,0031 \\
78\end{array}$ & $\begin{array}{c}0,17 \\
3\end{array}$ & $\begin{array}{c}\text { Distribusi } \\
\text { Normal }\end{array}$ \\
\hline
\end{tabular}

Berdasarkan tabel 3, Pengujian dilakukan pada taraf signigikansi $(\alpha=$ $0,05)$ untuk $\mathrm{n}=25$, didapat $\mathrm{L}_{\text {hitung kelas }}$ eksperimen sebesar 0,035627 dan $L_{\text {hitung }}$ kelas kontrol sebesar 0,003178 dan didapat $\mathrm{L}_{\text {tabel }}$ pada kedua kelompok pada taraf signifikan $\alpha=0,05$ sebesar 0,173 . untuk kedua kelas sampel harga $\mathrm{L}_{\mathrm{o}}<\mathrm{L}_{\mathrm{t}}$, dengan demikian dapat disimpulkan bahwa data tes hasil belajar kedua kelas sampel berdistribusi normal. Sehingga dengan demikian dapat dikatakan kedua kelas memiliki data yang berdistrbusi normal.

Setelah dilakukan uji normalitas kemudian dilakukan uji homogenitas variansi bertujuan untuk melihat data hasil tes belajar kelas eksperimen dan kelas kontrol mempunyai variansi yang homogen atau tidak homogen. Dalam uji homogenitas digunakan uji $\mathrm{F}$, setelah dilakukan perhitungan harga $\mathrm{F}$ dengan taraf $\alpha=0,05$ dari tabel distribusi $\mathrm{F}$ ternyata diperoleh harga $F_{\text {hitung }}<\mathrm{F}_{\text {tabel }}$ yaitu $1,08<1,67722$. Dapat disimpulkan bahwa data hasil tes akhir kedua kelas sampel memiliki variansi yang homogen.

Selanjutnya pengujian hipotesis dilakukan uji normalitas dan uji homogenitas variansi diketahui bahwa kedua kelas sampel memiliki data hasil belajar berdistribusi normal dan variansi yang homogen, maka untuk menguji 
hipotesis digunakan rumus t-tes.

Sebelum dilakukan uji t terlebih dahulu dihitung harga simpangan baku gabungan dari data kedua kelompok sampel yaitu :

$$
\begin{aligned}
& S=\sqrt{\frac{(n 1-1) s 1^{2}+(n 2-1) s 2^{2}}{n 1+n 2-2}} \\
& S=\sqrt{\frac{(25-1) 76.64+(25-1) 70,50667}{25+25-2}} \\
& S=\sqrt{\frac{(24) 76,64+(24) 70,50667}{48}} \\
& S=\sqrt{\frac{1.839,36+1.692,16008}{48}} \\
& S=\sqrt{\frac{3.531 .52008}{48}} \\
& S=\sqrt{73.57} \\
& S=8,577
\end{aligned}
$$

Selanjutnya digunakan rumus sebagai berikut :

$$
\begin{aligned}
& \mathrm{t}=\frac{x_{1}-x_{2}}{s \sqrt{\frac{1}{n_{1}}+\frac{1}{n_{2}}}} \\
& \mathrm{t}=\frac{68,16-62,72}{8,577 \sqrt{\frac{1}{25}+\frac{1}{25}}} \\
& \mathrm{t}=\frac{5,44}{8,577 \sqrt{\frac{2}{25}}} \\
& \mathrm{t}=\frac{5,44}{8,577 \sqrt{0,08}} \\
& \mathrm{t}=\frac{5,44}{8,577 \times 0,28} \\
& \mathrm{t}=\frac{5,44}{2,40}
\end{aligned}
$$

Dari distribusi $\mathrm{t}$ diatas dapat diketahui bahwa didapatkan $t_{\text {hitung }}$ sebesar $(2,26)$ dan $t_{\text {tabel }}$ pada taraf signifikan $(\alpha=0,05)$ adalah sebesar 1,67722. sehingga thitung $>$ ttabel $(2,26$ $>$ 1,67722), dimana Ho ditolak. hal ini berarti hipotesis penelitian diterima atau dapat dinyatakan bahwa terdapat pengaruh yang signifikan penggunaan model kooperatif tipe NHT terhadap hasil belajar kelas $\mathrm{V} \quad \mathrm{SDN} \quad 13$ Cingkariang Kecamatan Banuhampu Kab.Agam.

Pembahasan difokuskan pada hasil nilai tes akhir siswa pada kelas eksperimen nilai tertinggi adalah 84 dan nilai terendah 48 , nilai rata-rata 68,16 , varians 76,64 dan standar deviasi 8,39. Adapun perolehan nilai tes akhir kelas kontrol nilai tertinggi 80 dan nilai terendah yaitu 48, nilai rata-rata 62,72 , varians 70,50667 dan standar deviasi 8,3968 .

Hasil dari analisis menyatakan bahwa ada pengaruh yang signifikan dari variabel model Numbered Head Together (NHT) terhadap hasil belajar pendidikan kewarganegaraan di SDN 13 Cingkariang. Proses pembelajaran dengan menggunakan model kooperatif tipe Numbered Head Together (NHT) lebih bebas dan aktif dibandingkan dengan siswa yang belajar dengan metode ceramah bervariasi. 
Proses pembelajaran yang dilaksanakan menggunakan model NHT dapat mendorong aktivitas siswa. Hal ini terbukti banyaknya siswa yang bertanya, mengemukakan pendapat kepada guru atau temannya dalam kerja kelompok, mampu memperdalam pemahaman siswa, setiap kelompok memiliki tanggung jawab untuk menyampaikan hasil pendapatnya di depan kelas yang mana hal tersebut menuntut siswa untuk bias bekerjasama dalam kelompok.

Keaktifan belajar siswa dalam proses pembelajaran berdampak pada hasil belajar siswa menjadi lebih baik. Langkah-langkah NHT yang dilaksanakan dikelas eksperimen menurut Huda (2014;203-204) yaitu : 1) siswa dibagi kedalam kelompokkelompok, 2) masing-masing siswa dalam kelompok diberi nomor, 3) guru member tugas atau pertanyaan pada masing-masing kelompok untuk mengerjakannya, 4) Setiap kelompok mulai berdiskusi untuk menemukan jawaban yang dianggap paling tepat dan memastikan semua anggota kelompok mengetahui jawaban tersebut, 5) guru memanggil salah satu nomor secara acak, 6) siswa dengan nomor yang dipanggil mempresentasikan jawaban dari hasil diskusi kelompok mereka. Dengan menggunakan model NHT ini, siswa belajar dengan aktif didalam kelompoknya tanpa membeda-bedakan anggota kelompoknya serta dapat mempertanggung jawabkan tugas yang diberikan kepada setiap kelompok.

Pembelajaran di kelas kontrol yang diajarkan menggunakan pembelajaran konvensional dengan metode ceramah bervariasi. Menurut Bahri (dalam agustina 2017: 18-19) ceramah bervariasi merupakan cara penyampaian dan penyajian bahan pelajaran dengan disertai macam-macam metode pengajaran seperti Tanya jawab, diskusi dan pemberian tugas.

Dengan demikian pembelajaran di kelas kontrol yang di ajarkan dengan menggunakan pembelajaran konvensional yang menggunakan metode ceramah bervariasi dimana dengan menggunakan metode ini siswa masih pasif, kurang berinteraksi serta kesulitan dalam menerima pembelajaran di kelas karena hanya sedikit siswa yang mengeluarkan pendapatnya.

Dalam proses pembelajaran dikelas kontrol terlihat masih ada beberapa siswa yang tidak mengikuti pembelajaran dengan serius. Hal ini dibuktikan dengan adanya siswa yang bermain dan berbicara dengan teman sebangkunya sehingga mengganggu proses pembelajaran yang berlangsung. Hal ini menunjukan bahwa siswa dikelas kontrol kurang aktif dibandingkan 
dengan siswa kelas eksperimen. Sehingga hasil belajar dikelas kontrol lebih rendah dari hasil belajar siswa di kelas eksperimen.

Berdasarkan hasil analisis data posttest yang diperoleh dari hasil belajar kedua kelompok berdistribusi normal dan memiliki varian yang homogen. Hal ini menunjukan bahwa kondisi awal kedua kelas memiliki kondisi yang sama. Sehingga dapat dilakukan uji hipotesis dengan menggunakan statistik parametik mengggunakan rumus $\mathrm{t}$, didapatkan $t_{\text {hitung }}$ sebesar $(2,26)$ dan $t_{\text {tabel }}$ pada taraf signifikan $(\alpha=0,05)$ adalah sebesar 1,67722. sehingga thitung > ttabel $(2,26>1,67722)$, hal ini berarti hipotesis penelitian diterima. Kenyataan ini membuktikan bahwa model kooperatif tipe Numbered Head Together berpengaruh signifikan terhadap hasil belajar PKn kelas V SDN 13 Cingkariang Kecamatan Banuhampu Kab.Agam.

\section{SIMPULAN}

Berdasarkan hasil analisis data dapat disimpulkan bahwa terdapat pengaruh yang signifikan penggunaan model kooperatif tipe NHT terhadap hasil belajar pendidikan kewarganegaraan kelas V SDN 13 Cingakriang Kecamatan Banuhampu Kabupaten Agam. Pengaruh ini dapat dilihat dari hasil uji $t$ yang telah dilakukan, dimana $t_{\text {hitung }}$ yang diperoleh sebesar 2.26 dan ttabel pada taraf kepercayaan 0.05 adalah sebesar 1,67722 sehingga $t_{\text {hitung }}>t_{\text {tabel }}$ ini berarti hipotesis penelitian diterima. Kenyataan ini juga dapat membuktikan bahwa model pembelajaran kooperatif tipe NHT berpengaruh signifikan terhadap hasil belajar Pendidikan Kewarganegaraan kelas V di SDN 13 Cingakariang Kecamatan Banuhampu Kabupaten Agam.

DAFTAR RUJUKAN

Agustina, Eka.2017. Skripsi Penerapan Metode Ceramah Bervariasi untuk Meningkatkan Aktifitas Belajar Siswa Pada Mata Pelajaran Pendidikan Kewarganegaraan Kelas XI IPS-4 SMAN 1 Ketapang. Bandung : UPB

Arikunto, Suharsimi. 2010. Prosedur Penelitian suatu Pendekatan Praktis. Jakarta : PT Rineka Cipta Hamdayana, Jumanta. 2014. Metode dan Model Pembelajaran Kreatif dan Berkarakter .Bogor : Ghalia Indonesia

Huda, Niftahul. 2014. Model-model Pengajaran dan Pembelajaran. Yogyakarta: Pustaka Belajar

Kurniasih, Imas, dkk.2015. Ragam Pengembangan Model Pembelajaran untuk Peningkatan 
profesionalitas Guru.Yogyakarta :

Kata Pena

Sugiyono. 2012. Metode Penelitian

Pendidikan:

Pendekatan
Kuantitatif, Kualitatif, dan $R \& D$.

Bandung: Alfabeta. 